Noritada Matsuda

\title{
Can Universities Supply Citizenship Education?
}

\section{A Theoretical Insight}

This article focuses on citizenship education supplied by universities as a way to help promote citizen participation. Employing an economic approach to university behavior in a competitive market, theoretical insight is offered into whether universities can supply citizenship education. The findings reveal, on the one hand, that universities have an incentive to educate "good citizens" and that subsidies, including governmental financial support, contribute both to an increase in the number of students and to an improvement in citizenship education programs. It is demonstrated, on the other hand, that universities are unenthusiastic about supplying education for "adequate citizens." Universities emphasize commercial revenue rather than citizen development, and although governmental financial support might allow more individuals to receive an education, this is unlikely to be spent almost exclusively on citizenship education programs.

KEYWORDS: citizen participation, citizen development, citizenship education, university education, university competition

Noritada Matsuda is an Associate Professor at Aoyama Gakuin University. The author wishes to thank Dr. Yoshitaka Tsuruta (Aoyama Gakuin University, formerly Kanazawa University) for his helpful advice on economic perspectives on university behavior in a competitive market. As usual, mistakes must be attributed to the author. 
THE IDEA OF CITIZEN participation-that every individual should participate in the policy process-has been long accepted as a pillar of democracy. Nowadays, lamenting the lack of responsiveness of legislative and executive branches to social needs, many social scientists, especially scholars of political science, public administration, and public policy are emphasizing citizen participation in different ways from traditional views based on representative democracy, and are placing more demands on citizens. The recent stress on citizen participation regards citizens as "active participants in the community as well as in the polity, contributing to the common welfare, to the economy's wealth production and, most significantly, sharing in the rights and responsibilities of the polity" (RANSON and STEWART 1989, 14-15, emphasis added).

Such expectations toward individuals entail reconsidering what is required of "citizens" in a democracy: the competence of citizens ceases to be taken as a given (MATSUDA 2011). Representative democracy has assumed that not every individual has the knowledge and capacity to judge in the policy process and that the primary role of citizens is to vote in an election; how to get a competent representative has thus been a crucial question for representative democracy. In the citizen participation that is emphasized today, on the other hand, the problem of the competence of individuals is seen as more critical; if individuals with little knowledge or capacity are actively engaged in the policy process (e.g., policy formulation and evaluation), this could have a severe and negative impact on society. The promotion of active citizen participation needs to be accompanied by tackling the problem concerning citizen development: namely, the problem of how to enhance an individual's competence and to help them develop into a "citizen."

Given that competence is "neither naturally given nor durable once achieved" (OFFE 1997, 81), studies on democracy and public policy are today placing particular emphasis on education that contributes to citizen development-that is, citizenship education. Through citizenship education, individuals are expected to learn democratic values and dispositions on one side, and knowledge and skills on the other (PATRICK 2003; Ross 2004; Veugelers 2007). Democratic values and dispositions are regarded as essential for individuals to play a vital role in democracy. Such a role for individuals, moreover, is more meaningful if they have adequate knowledge and skills to be engaged in the policy process.

As for the goals of citizenship education, different researchers present different views. Many focus on children and youths and regard elementary and secondary education as responsible for citizenship education (BIESTA 
and LAWY 2006; PARKer 2001; Ross 2004). Others emphasize actors who have the right to participate in the policy process, namely, adults; closer attention is then given to citizenship education conducted by NPOS and universities (Matsuoka 2011; Annette and McLaughlin 2005; MatSUDA 2013a).

Turning to what (and how) to learn in citizenship education, recent philosophical research has focused primarily on what citizenship means and has suggested the content of citizenship education (BEINER 1995; HEATER 1999; KODAMA 2003; OKANO 2009; VAN STEENBERGEN 1994). Scholars on educational policy and teaching methodology, on the other hand, have conducted case studies to develop an effective curriculum for citizenship education (EGUCHI et al. 2010; Minei 2007; NinOMiYa 2007).

Whereas there is a great deal of expectation toward citizenship education, few studies have, however, thoroughly scrutinized its feasibility. Even if one successfully designs an effective curriculum for citizenship education, it may not necessarily work in practice. The subjects to be examined, in this sense, include not only what to learn in citizenship education itself. Closer attention also needs to be paid to how it works and how various actors behave in the realm of citizenship education (MATSUDA 2013b).

These latter points are scrutinized in this article. The particular focus here is on citizenship education at the university level. Theoretically analyzing university decision-making on whether or not to conduct citizenship education, the following question is explored: Can universities supply citizenship education?

This article proceeds as follows. The next (second) section clarifies why citizenship education in universities deserves analytical attention, and what vital roles universities are expected to undertake in citizenship education. The third section, relying on economic literature, models university behavior in the contemporary competitive market. With the goals of universities derived in the third section, the fourth section offers theoretical insights into the supply of citizenship education in university education, and takes a close look at whether universities would be willing to provide citizenship education. The fifth section concludes by presenting some limitations of the analysis and suggesting some implications for enriching citizenship education in universities.

\section{Universities and Citizenship Education}

There is the popular perception, as stated above, that elementary and secondary education should be immediately responsible for citizenship educa- 
tion; on the other hand, higher education, including university education, is likely to be seen as irrelevant to citizenship education (ENGLUND 2002; AnNetTe and McLaughlin 2005). ${ }^{1}$ Can university education contribute to citizen development? This section illuminates two critical peculiarities of university education that make universities capable of playing vital roles in citizenship education (MATSUDA 2013a), and reveals why citizenship education in universities deserves analytical attention.

First, the targets of a university education differ from those of elementary and secondary education. University students are older and more experienced than those in elementary and secondary schools. Second, university education is characterized by facilitating "non-situated learning," the same as elementary and secondary education. "Non-situated learning" aims only at learning, whereas "situated learning" is defined as learning that takes place in the course of an activity (LAVE and WENGER 1991). These two peculiarities matter in citizen development.

Although citizenship education is widely regarded as acquired by children and youths, this article focuses particularly on the affirmation that citizenship education be targeted also at adults. Adults should be included in the targets for citizenship education since there are some qualities and abilities that are difficult for children and youths to acquire. Philosophical perspectives, for instance, are indispensable in policy debates (ADACHI 1994; 2005). There has been a long history of philosophical controversy concerning what a society should be like, and no single clear answer has been found yet. Such perspectives can restrain an individual from absolutizing their view and foster constructive conflict in the policy process.

Technical knowledge and skills are also crucial for an individual to be actively engaged in the policy process. Some point out, for instance, that an individual is likely to give little attention to budget or resources; consequently, citizen participation tends to result in abstract discussions, giving more discretionary power to government agencies (SATO et al. 2005). What is implied here is that knowledge on how to finance policies is of critical significance to policy deliberation. If an individual without technical knowledge and skills plays an active role in the policy process, the policy instrument adopted might have a negative impact on society.

1. The Japanese Journal of Higher Education Research (published by the Japanese Association of Higher Education Research), for instance, featured "A Decade of Higher Education Research" in 2007 and "The Transformation of Universities" in 2009; neither volume contained articles making direct reference to citizenship education. 
Not all of these qualities and abilities are expected to be successfully acquired when an individual is young. There are some that can be effectively learned by an individual who is participating or will soon participate in the policy process. In addition to elementary and secondary education, education that is targeted at adults-actors in citizen participation-significantly contributes to citizen development (Matsuoka 2011; Matsuda 2009).

Universities are not the only places, however, where adult learners could acquire qualities and abilities useful for citizen participation. Adult learning is considered to be facilitated via citizen participation itself; it is in activities dealing with social problems, as many have affirmed, that an individual is likely to acquire such qualities and abilities. One of these activities is participation in NPOS (MATSUOKA 2011).

Learning through citizen participation, which is characterized by situated learning, can lead to an alteration of consciousness and the acquisition of practical wisdom (SCHÖN 1983; TANAKA 2011; Miwa 2009). Participating in the policy process helps an individual understand what role they have to play in a democracy; such understanding is essential to democratic values and dispositions. Citizen participation also encourages an individual to build practical knowledge, which contributes to their tackling a particular social problem.

Citizen development, however, needs more than just this kind of learning. University education can make an indispensable contribution to citizen development through an education that facilitates non-situated learning. For clarification, let us turn to the distinction between learning and education.

Learning is denoted by a behavioral change through experience; one may say that learning has occurred if a long-term change is identified before and after some experience. It should be noted that this change is not necessarily "progress" and, hence, that learning is seen as self-centered (Aso and HorI 1997). Given the "self-directedness" of adults in learning activities (KNOwLES 1980), adult learning is more likely to fall into self-satisfaction.

It follows that if learning only through self-directedness, an individual has much difficulty being an active player in a democracy. Attention needs to be given to systematic education on the basis of ideas of democracy and citizen participation, which facilitates non-situated learning: namely, education for citizen participation (MATSUDA 2013a).

Educational activities that support non-situated learning for citizen participation have been conducted, for instance, by NPOs. Some NPOs provide their staff members with learning opportunities-e.g., conducting workshops and allowing the members to go for training-whereas others hold lectures relevant to citizen participation (TANAKA 2004; TsUCHIYAMA 
and Ohyano 2008; Tsujl 2004). This article, on the other hand, puts more emphasis on the expected contribution of universities to citizen development, which NPOs are unlikely to make.

First, universities have been considered to embody "universalism" (BARNETT 2005; KOIKE and SATO 2004): universities should be neither partial (they should inquire into the truth and create new knowledge) nor local (they should have society-wide missions). ${ }^{2}$ The aforementioned philosophical perspectives and technical knowledge and skills are critical in any context of citizen participation, and not specific to a certain situation or case. What such universal perspectives, knowledge, and skills should be like has long been explored in universities and can be effectively learned there. Second, those perspectives, knowledge, and skills are difficult to acquire through short-time and one-shot learning. Universities could contribute to citizen development by providing systematic and continuing educational programs on philosophy, public policy, and so on.

\section{Universities and a Model of University Behavior}

\section{ECONOMIC STUDIES ON UNIVERSITIES}

The preceding section illuminates the expected contribution by universities to citizenship education. One question arises here: are such expectations realistic? This is regarding the feasibility of university education for citizen development. As the first section states, however, citizenship education has not been thoroughly scrutinized in terms of its feasibility. This article thus is intended as a theoretical inquiry into the feasibility of university education for citizen development.

This task requires particular attention to the decision-making of-and interactions among-actors relevant to university education for citizen development. Citizenship education programs in universities, the same as regular programs of university education, are not compulsory. This means that an individual can choose to receive an education and also that a university is to some extent free to design its educational programs. How university education for citizen development would work thus depends on individuals' and universities' decisions, namely on the demand and supply of education.

This article employs economic perspectives on university education to examine various actors' decision-making processes and interactions in uni-

2. For contemporary challenges to the universalism of universities, see BARNETT (2005). 
versity education for citizen development. University education has recently been attracting more attention in the field of economics (e.g., Clotfelter et al. 1991; Clotfelter and RothsChild 1993a). Economists analyze university education through applying models of other industries to it and deal mainly with two basic questions (CLOTFELTER and RothSCHILD 1993b, 3). First, what mix of products does the university education industry produce, and at what cost? This question focuses on the supply side of university education. Emphasizing the market contexts of universities and the competitive nature of university education, analyses are conducted regarding universities' competition for faculty, students, research grants, contributions, and government subsidies; relatedly, attention is paid to university decisionmaking, for instance on positioning in the marketplace, prices (e.g., tuition and fees) and production levels (the number of students to admit), and the timing of entering new markets (e.g., offering new programs and establishing new schools; RotHSCHILD and White 1993, 11).

The second question is related primarily to the demand side. Focusing on who pays for the products produced by universities and who benefits from them, economic explanations are offered on individual behavior, such as receiving and giving education to someone (e.g., a child). Some regard university education as an investment (BECKER 1964; SPENCE 1973) whereas others see it as consumption (OsHIO 2002).

Both of these two points are also essential to explore how university education for citizen development would work. This article particularly looks into the supply side; in this sense, the analysis here is designed to serve as a small, but crucial, step toward understanding the mechanisms of university education for citizen development. ${ }^{3}$

\section{GOALS OF UNIVERSITIES}

The remainder of this section models university behavior in a competitive market. Specifically, the goals of universities are clarified through relying on the economic literature on university education. ${ }^{4}$

One can find analyses that emphasize university preferences on incoming students. Avery and Levin (2010), for instance, describe universities that prefer students with a high ability and those who are eager to attend;

3. The complementary relationship between the supply and demand analysis on citizenship education in universities is mentioned in the concluding section.

4. It should be noted that this article does not deal with the goals of faculty members; rather, clarification is conducted regarding goals of university organizations or university managers. 
to accomplish this objective, each university strategically makes a decision on admission. There are also other studies focusing on university activities other than the selection of students, such as teaching and research activities. Universities aim, Del Rey (2001) avers, at maximizing the increase in total productivity of their students and total utility derived from research (see also Boroonh 1994). ${ }^{5}$ In still other studies, moreover, goals of universities are illuminated in another way. Stressing that few universities are for-profit firms, Winston (1999) insists that the classical goal of profit maximization is not applicable to universities.

Such diversity in university goals is regarded as being derived from one characteristic of university education: customer-input technology (RотнSCHILD and WhITE 1995). For universities, students are inputs as well as customers. Students as customers pay tuition fees to contribute to the increase in a university's profits; ${ }^{6}$ students are, at the same time, a crucial input to university education in that they significantly influence the quality of education.

The customer-input technology in university education makes the selection of students critical for universities to operate. Universities need to attract enough students for the revenues to cover their running costs. Therefore it is imperative that universities create and increase the demand for their educational programs. Thus, a key question to ask is what educational programs to offer. If universities provide educational programs that produce quality graduates, for instance, they are likely to receive more applications.

However, universities must think about the quality, and not only the number, of incoming students. Whether an educational program can produce quality graduates depends significantly on the quality of students. Whereas universities have to compete for good students, one effective strategy for winning the competition is to subsidize good students (WINsTON 1999), using for example scholarships and fellowships. ${ }^{7}$ How could this strategy work?

5. As to the relationship between university utility and teaching and research activities, JAmes and Neuberger (1981) present a different view. In their model, teaching is described as a profitable but low-utility activity, which subsidizes unprofitable but high-utility activities such as research.

6. In many European countries, where governments bear the costs of university education, universities get government funds as a result of the enrollment of a student; in this sense, students are customers of university education in those countries (DEL REY 2001).

7. Another strategy is early admission, which helps universities get good students at earlier stages (Avery et al. 2004; Avery and Levin 2010). 
Utilizing the classification by HANSMANN (1981) of revenue sources of nonprofit organizations, WINSTON (1999) defines universities as "donativecommercial nonprofits." Donative-commercial nonprofits are organizations that have two sources of revenue: charitable donations and sales proceeds. Charitable donations are "broadly defined as legislative appropriations, current gifts, and asset earnings from the accumulated past donations embedded in endowment and physical plant"; sales proceeds, on the other hand, take "the form of net tuition receipts" (WINSTON 1999, 16).

Although the subsidy strategy entails a decrease in commercial revenues (namely, tuition receipts), it could work for the following reason. Good students can enhance their abilities through university education and will play a vital role in society after they graduate. Their success in society will then raise the prestige of the university. Its heightened prestige, consequently, will allow the university to get more donations, which compensates for the decline in tuition receipts.

Higher ability applicants stress the prestige of a university for at least two reasons. First, individuals with high ability pay careful attention to the educational outcome of each university; they prefer more prestigious universities because the prestige signals that the universities have produced-and will continue to produce - high quality graduates. Second, given that universities with high prestige have more revenues derived from a large amount of donations, they are expected to employ quality faculty members and to improve their facilities in order to arrange much better educational programs.

When high ability individuals choose among universities with high prestige, subsidies can be an important factor for their choice. Every university thus has an incentive to adopt a subsidy strategy to attract many good students, even if this strategy reduces tuition receipts.

What is suggested here is that a university can be modeled as a "prestige maximizing" entity if they have a single-valued objective function (WinstON 1999; JAMES 1990). Any activity aimed at getting good students, producing quality graduates, and arranging better educational programs serves as a means to enhance university prestige. This article thus emphasizes the maximization of prestige as the primary goal of a university.

\section{Universities and the Supply of Citizenship Education}

\section{UNIVERSITY EDUCATION AND IDEAS ABOUT “CITIZENS”}

Applying the model of university behavior presented in the preceding section to university decision-making on whether or not to supply citizenship 
education, this section theoretically scrutinizes the feasibility of citizenship education at the university level. The analysis begins with looking into the following question: what is required of citizens in citizen participation? Dealing with this question is critical since different ideas call for different citizenship education programs. Numerous attempts have been made to solve this question and various answers have been presented. The focus here is placed on just two ideas about what constitutes a citizen, which differ in the capacity and knowledge a citizen should have (MATSUDA 2011).

The first idea is that of the "good citizen," and makes strong demands on citizens: they should be highly concerned about public affairs, wellinformed about issues and political actors, skillful enough to pursue their interests, and motivated by a desire to foster the general welfare (DAHL 1992, 46; NIE et al. 1996, 15). ${ }^{8}$ This concept of a citizen is rooted partly in "citoyens actifs (active citizens)" during the French Revolution (MATsuda 2009). Given that citizen participation necessitates sophistication, theorists such as Emmanuel-Joseph Sieyès (SIEY Ès 1985a; 1985b, quoted in SAKAGAMI 1992) and Jean-Denis Janjuinais (from his presentation about the draft constitution on April 29, 1793, quoted in SUGAWARA 2001) averred that the right of political participation be granted only to citoyens actifssophisticated individuals who have sufficient knowledge to exercise their rights and can exercise reason (usage de la raison).

In the other idea about what constitutes a citizen, not every individual is required to have such expertise and intellect. Instead, emphasis is placed on the "ordinary knowledge" or "local knowledge" of individuals. Knowledge of this kind differs from expertise created through academic and professional research activities; it consists of what one experiences and feels in their daily lives. In many cases where citizen participation has been promoted, individuals are expected to provide their ordinary knowledge in the policy process (AKIYOSHI 2003; BRYANT 2002). This idea can be referred to as the idea of the "adequate citizen" (DAHL 1992).

Some might see the idea of the good citizen as too demanding; in this sense, the idea of the adequate citizen would be more reasonable. If individuals who lack the technical knowledge or capacity are to be allowed to participate in the policy process, however, their activities need to be supported and facilitated by some actors so that the negative impact of such

8. DAHL (1992) calls this view of the good citizen the classical one. He also mentions the modern view of the good citizen, which regards citizens as moved by their self-interest. If the latter view is taken, he argues, the problem of citizen competence is reduced to that of knowledge alone. 
citizen participation could be mitigated. This supporting and facilitating role cannot be successfully undertaken by actors who have little technical knowledge and capacity; good citizens are expected to play this role. Therefore, even when the idea of the adequate citizen is taken up, the idea of the good citizen is still seen as crucial to citizen participation (MATSUDA 2013a).

When citizenship education aims at developing individuals into good citizens, universities are expected to contribute to citizen development by conducting professional education. Recently, in various countries, including the United States and Japan, many universities offer professional graduate and undergraduate programs on public affairs (TsuchiYama and OHYANO 2008). These programs are capable of helping individuals acquire scientific knowledge and skills regarding policy analysis, design, and evaluation, and technical knowledge on laws and management that are indispensable to policy implementation. ${ }^{9}$

Turning to citizenship education on the basis of the idea of the adequate citizen, universities are expected to provide basic knowledge on the policy process and political institutions (RoberTs and EKsterowics 1996) and philosophical perspectives and knowledge (Nussbaum 1997; AnNette and MCLAUGHLIN 2005). Such perspectives and knowledge are indispensable for any individual to participate in the policy process. In this sense, it is preferable that university education of this kind be acquired by as many individuals as possible. Specifically, it should be offered not only to full-time students; opportunities for this education need to be opened to various individuals, for instance, through university extension programs. ${ }^{10}$

\section{UNIVERSITY EDUCATION FOR GOOD CITIZENS}

Given the ideas about citizens presented above and assuming universities are entities that maximize prestige, the remainder of this section theoretically examines the following question. Do universities have an incentive to contribute to citizenship education?

9. In addition, basic knowledge on social sciences, philosophy, and logic need to be taught in the educational programs based on the idea of the good citizen. This is because technical knowledge will be of no use or dangerous to democracy unless it is grounded in such basic knowledge (ADACHI 2005).

10. There are two types of university extension programs: an extension of university teaching, and functional extension (Shannon and Schoenfeld 1965). The former opens opportunities of formal university education to part-time students; in the latter type, educational programs distinct from regular ones are provided (e.g., extension courses). 
The analysis here is conducted first on the feasibility of university education for good citizens. One way to conduct education of this kind, as stated above, is professional education on public affairs. If a certain professional educational program can successfully develop individuals into good citizens, they will facilitate and lead the policy process; this vital role of facilitator and leader will be highly valued in society. A university offering such an educational program will succeed in attracting much social attention. Conducting university education for good citizens, if it works well, could contribute to university prestige, which is the goal of universities. It follows that universities would be willing to supply this type of citizenship education.

Universities have an incentive to adopt the subsidy strategy. A key to the citizenship education of this type is to attract as many good students as possible; subsidizing good students, as stated above, helps accomplish this. The subsidies also serve a social goal, not only the goals of universities. This strategy allows a larger number of competent individuals to acquire citizenship education at the university level than in the case of no subsidies. University tuition is far from cheap, whether undergraduate or graduate professional programs; there are therefore quite a few individuals that decide to give up on going to university. Subsidies such as scholarships and fellowships help those individuals to attend university. If subsidies provide an opportunity for competent individuals to acquire university education regardless of the amount of income they have, citizen participation is expected to be more meaningful.

The impact of subsidies on citizen participation can be more significant if governments provide universities with financial support for citizenship education. Governmental financial support increases the amount of subsidies universities can give to good students, and then a larger number of competent individuals are able to go to university. Universities are willing, moreover, to spend government subsidies on improving their educational curricula; the universities can produce a larger number of quality graduates through the improved educational curricula, and, consequently, the prestige of the universities will be enhanced.

\section{UNIVERSITY EDUCATION FOR ADEQUATE CITIZENS}

University education for adequate citizens is essential to citizen participation in that this type of citizenship education helps individuals acquire basic knowledge and philosophical thinking. What is learned is regarded as a minimum requirement for citizen participation. It is desirable that this type of citizenship education be received by as many individuals as 
possible; one way to provide many individuals with an opportunity for citizenship education is through university extension programs.

However, despite the crucial significance of university education for adequate citizens, just what this type of citizenship education could yield for universities is unclear. Specifically, there are at least two difficulties. First, universities do not necessarily have the incentive to supply this type of citizenship education. Many universities now offer various extension courses to cope with increasing demand. Within society, however, attention is likely to be paid almost exclusively to whether a university has extension courses; the impact of the courses on a student-e.g., the difference in a student's ability before and after participating in the courses-does not necessarily matter when evaluating the university. In this situation, universities are not inclined to arrange systematic and continuing educational programs that aim at developing individuals into adequate citizens because such educational programs would not significantly influence university prestige. Focusing on commercial revenues, effort is likely to be made to increase the number of enrollments; consequently, the educational programs offered would be those that overemphasize student needs even if they are irrelevant to citizen development.

Second, there are many individuals who cannot afford the cost of educational programs, and this problem exists for both adequate citizens and good citizens. The problem can be reduced in the case of university education for good citizens by subsidizing some students. In the case of education for adequate citizens, however, universities have little incentive to adopt the subsidy strategy. This strategy entails a decline in commercial revenues (namely, the amount of money students pay), whereas universities cannot expect an increase in donations that compensate for the negative impact of subsidies on revenues.

One might stress governmental financial support to deal with this problem. It is true that governmental financial support provides more individuals with opportunities to acquire a university education. Again, however, citizen development does not lead easily to an increase in university prestige in the case of education for adequate citizens. Government subsidies are unlikely to be spent on arranging educational curricula for citizen development. ${ }^{11}$

11. Given these difficulties in supplying university education for adequate citizens, some may expect individual faculty members, not universities or departments as a whole, to be suppliers of citizenship education (KOIDE 2003). If citizenship education is supplied in this 


\section{Concluding Remarks}

Given the growing gap between social needs and government activities, how to improve the policy process has been the critical question for the revival of democracy. To tackle this question, many have been emphasizing citizen participation. The conditions essential to the promotion of citizen participation include citizen development: an individual should develop into a citizen. As one way to help meet this condition, much attention is now being centered on citizenship education, which can be-and has been-conducted in various ways. This article has focused particularly on citizenship education at the university level and has scrutinized its feasibility in terms of the supply side. Specifically, universities are modeled as prestige maximizers from an economic perspective, and then theoretical insight is offered into whether universities can supply citizenship education.

The findings of this article demonstrate, on the one hand, that universities have an incentive to supply education for good citizens, and that subsidies, including governmental financial support, contribute both to an increase in the number of students and to an improvement in educational programs. On the other hand, universities are unenthusiastic about supplying education for adequate citizens; in citizenship education of this kind, commercial revenue takes precedence over citizen development; governmental financial support might allow more individuals to be educated, but is unlikely to be spent almost exclusively on citizenship education programs.

The analysis in this article is preliminary and designed as a starting point for understanding the mechanism of university education for citizen development. Two methods of analysis development are referred to below.

First, this article regards a university as an almost unitary actor; the assumption is that every university is located in the same or similar environment and has the same or similar preferences and goals. It is more reasonable, however, to assume that universities behave differently in their respective environments, and that they have different preferences and goals.

Romero and Del Rey (2004), for instance, distinguish between public schools and private schools. The two types of universities differ in revenue sources and have different goals; they conduct different educational programs,

way, however, universalism, systematicness, and continuity would be difficult to take into account. As SATO (2009) points out, moreover, if some faculty members apply for a competitive grant to conduct citizenship education, those faculty members would be overburdened and their ordinary daily activities in their workplaces might be undermined. 
consequently, in terms of quality of education, standards of admission, and so on. Competitive environments surrounding universities, moreover, vary according to university ranking (DoI 2007; MARGINSON 2006): higher-ranking universities are facing intense global competition; intermediate universities are open to fierce national competition; and lower-ranking universities are competing for students, caring about the quantity, rather than quality, of students. Such different competitive environments incline different universities to have different goals and to adopt different admission strategies (AverY and Levin 2010). By taking into account such heterogeneity of universities, the analysis could reveal a wider variety of ways for universities to deal with citizenship education.

Second, one may point out a gap between the findings of this article and reality. This article demonstrates that universities have an incentive to supply education for good citizens whereas not many universities provide professional programs on public policy. The same gap exists in the case of education for adequate citizens; inconsistent with the analysis results of this article, there are many university extension programs.

One factor responsible for the gap is this article's almost exclusive focus on the supply side of education and on university behavior. If one is to explore the feasibility of university education for citizen development, the demand for education should also be investigated. Given that university education is not compulsory, an individual's preferences and the constraints on their behavior significantly influence how they make a decision on whether or not to acquire citizenship education and what kind of citizenship education is more likely to be chosen (MATsUdA $2013 \mathrm{~b}$ ). Individuals having the incentive to enter a professional school on public affairs, for instance, consist mainly of those who want to change existing policy programs and hence possess different preferences from policymakers; in this situation, even if they finish their educational program, their voices may not be seriously listened to by policymakers, and they would get demotivated to invest in professional programs. Despite the incentive to supply professional programs, universities are prevented from doing so by individuals' preferences and interactions with other actors.

With regard to university extension programs, as previously mentioned, universities tend to stress the increase in commercial revenues and the quantity of students; given that individuals are likely to "consume" university extension programs that directly increase their utility (FUKUDOME 2006; SUEмото 2004), universities are inclined toward arranging extension programs on the basis of consumer preference, even those irrelevant 
to citizenship education. There will be, consequently, few university extension programs that are closely related to citizenship education. ${ }^{12}$ Through combining such demand and supply side studies, the research into the feasibility of citizenship education can flourish.

Despite the limitations of the analysis in this article, however, its findings have notable implications for the question of what can help universities to play their expected role in citizenship education. Here this article concludes by briefly suggesting the implications.

The analysis conducted here places emphasis on prestige maximization as the primary goal of universities. Given this description of universities, it follows that the enrichment of citizenship education in universities depends on whether university prestige can be heightened when universities produce quality graduates (namely, "citizens") through citizenship education. For instance, as revealed above, universities have no or little incentive to supply education for adequate citizens as it does not significantly matter for the evaluation of a university whether such citizenship education is successfully conducted or not.

If, nevertheless, one is to see university education for citizen development as essential to citizen participation and to make such education work, then what will be of help? One answer to this question would be that the potential role of universities in citizenship education needs to be widely known in society. In a situation where universities successfully producing citizens are highly rated by society, as entities that maximize prestige, they are given incentives to seriously work on citizenship education and citizen development.

How to make university education for citizen development work, in this sense, goes far beyond the question of the institutional design of universities. In addition to actors who directly take part in university education, every member of society affects how citizenship education would work in universities. The enrichment of citizenship education in universities and eventually the promotion of citizen participation can be seen as a movement every member of society should be actively involved in.

12. For a theoretical, demand side analysis of citizenship education, see MATsUdA (2013b). 


\section{REFERENCES}

ADACHI, Y.

2005 "Kokyoseisaku-gaku wa Ikanaru Gakumon toshite Naritachi Urunoka" (Theory of public policies as a discipline). In Seisakugaku-teki Shiko to wa Nanika: Kokyoseisaku-gaku no Kokoromi (Modes of thinking in the policy process: Toward a general theory of public policies), ed. Y. Adachi, 1-18. Tokyo: Keiso Shobo.

1994 Kokyoseisaku-gaku Nyumon: Minshushugi to Seisaku (Introduction to the theory of public policy: Democracy and public policy). Tokyo: Yuhikaku.

AkiYoshi, T.

2003 "On the Knowledge Utilization in the Japanese Public Policy Making." Kumamoto University Studies in Social and Cultural Science 1: 17-30.

Annette, J., and T. MCLaughlin

2005 "Citizenship and Higher Education in the UK." In Citizenship and Higher Education: The Roles of Universities in Communities and Society, J. Arthur and K. E. Bohlin, eds., 56-72. Oxon: RoutledgeFalmer.

Aso, M., and S. Hori

1997 Shogai Hattatsu to Shogai Gakushu (Lifelong development and lifelong education). Tokyo: Foundation of the Promotion of the Open University of Japan.

Avery, C., A. Fairbanks, and R. Zeckhauser

2004 The Early Admissions Game: Joining the Elite. Cambridge. MA: Harvard University Press.

Avery, C., and J. Levin

2010 "Early Admission at Selective Colleges." American Economic Review 100: $2125-56$.

BARNETT, R.

2005 "Recapturing the Universal in the University." Educational Philosophy and Theory 37: 785-97.

BECKER, G. S.

1964 Human Capital: A Theoretical and Empirical Analysis, with Special Reference to Education. New York: National Bureau of Economic Research (Distributed by Columbia University Press, New York).

BEINER, R., ed.

1995 Theorizing Citizenship. Albany: State University of New York Press.

Biesta, G., and R. LAwY

2006 "From Teaching Citizenship to Learning Democracy: Overcoming Individualism in Research, Policy and Practice." Cambridge Journal of Education 36: 63-79 
Borooah, V. K.

1994 "Modelling Institutional Behaviour: A Microeconomic Analysis of University Management.” Public Choice 81: 101-24.

BRYANT, T.

2002 "Role of Knowledge in Public Health and Health Promotion Policy Change." Health Promotion International 17: 89-98.

Clotfelter, C. T., R. G. Ehrenberg, M. Getz, and J. J. Siegfried

1991 Economic Challenges in Higher Education. Chicago: University of Chicago Press.

Clotfelter, C. T., and M. Rothschild, eds.

1993a Studies of Supply and Demand in Higher Education. Chicago: University of Chicago Press.

1993b “Introduction.” In Clotfelter and RothsChild 1993a, eds., 1-10.

DAHL, R. A.

1992 “The Problem of Civic Competence." Journal of Democracy 3: 45-59.

Del Rey, E.

2001 "Teaching versus Research: A Model of State University Competition." Journal of Urban Economics 49: 356-73.

DoI, R.

2007 "Structural Analysis of the Competitive Environment for Education and Research Provided by Universities in Japan.” RIETI Policy Discussion Paper Series 07-P-o03. http://www.rieti.go.jp/jp/publications/ pdp/o7poo3.pdf (accessed April 10, 2014).

Eguchi, Y., Y. IDA, J. ITo, and K. KARAKI, eds.

2010 Shimin Kyoiku e no Kaikaku (Reform toward civic education). Tokyo: Tokyo Shoseki.

ENGLUND, T.

2002 "Higher Education and Citizenship: The Democratic Potential of the University?" Studies in Philosophy and Education 21: 81-287.

Fukudome, T.

2006 "Research on the Role and Effect That a Community College Has on Community Development: An Examination from the Actual Practice of Mature-Adult Colleges in Two Towns." Shogai Gakushu Kenkyu 4: 63-80.

HANSMANN, H.

1981 "The Rationale for Exempting Nonprofit Organizations from Corporate Income Taxation." The Yale Law Journal 91: 54-100.

HeAter, D.

1999 What is Citizenship? Cambridge: Polity Press.

JAMES, E.

1990 “Decision Processes and Priorities in Higher Education.” In The Eco- 
nomics of American Universities: Management, Operations, and Fiscal Environment, S. A. Hoenach and E. L. Collins, eds., 77-106. Albany: State University of New York Press.

James, E., and E. Neuberger

1981 "The University Department as a Non-Profit Labor Cooperative." Public Choice 36: 585-612.

KNOWLES, M. S.

1980 Modern Practice of Adult Education: From Pedagogy to Andragogy. Englewood Cliffs: Cambridge Adult Education.

Kodama, S.

2003 Shitizunshippu no Kyoiku Shiso (Educational thought of citizenship). Tokyo: Hakutakusha.

KoIde, Y.

2003 "A New Method of Citizens' Education of Liberal Arts from a University." Social Information 13: 19-28.

KoIke, G., and S. SATO

2004 "Koto Kyoiku Kikan to Seijin Gakushusha" (Higher education institutions and adult learners). In Seijin no Gakushu to Shogai Gakushu no Soshikika (Adult learning and development of lifelong-learning systems), ed. The Japan Society for the Study of Adult and Community Education, 246-62. Tokyo: Toyokan.

LAVE, J., and E. Wenger

1991 Situated Learning: Legitimate Peripheral Participation. New York: Cambridge University Press.

MARginson, S.

2006 "Dynamics of National and Global Competition in Higher Education." Higher Education 52: 1-39.

Matsuda, N.

2013a "Higher Education for 'Citizens': Universities in Citizenship Education." Journal of Law and Political Science 40: 453-89.

2013b "Sentaku toshiteno Shitizunshippu Edyukēshon: Shimin Sanka notameno Kyoiku wa Kinosuru no ka?” (Citizenship education as an individual's choice: Can education for citizen participation work?). Public Administration Review Quarterly 141: 17-30.

2011 "Gabanansu no Shutai toshiteno Shimin" (Citizens as actors in governance). In Gabanansu-ron no Genzai: Kokka o meguru Kokyosei to Minshushugi (What governance studies are), ed. M. Iwasaki, 93-116. Tokyo: Keiso Shobo.

2009 "Citizens in the Era of Governance: Citizen Participation and Active Citizenship." Interdisciplinary Information Sciences 15: 231-42. 
Matsuoka, H.

2011 "Minshushugi Shakai no Sozo to Shitizunshippu" (Creation of democratic society and citizenship). In Shogai Gakushu no Kiso (Foundations of lifelong learning), M. Suzuki, K. Nagai, and Y. Nashimoto, eds., 20012. Tokyo: Gakubunsha.

Minei, A., ed.

2007 Sekai no Shitizunshippu Kyoiku: Gurobaru Jidai no Kokumin/Shimin Keisei (Citizenship education in a global age: Comparative and transnational perspectives). Tokyo: Toshindo.

Miwa, K.

2009 Otona no Manabi wo Hagukumu: Shogai Gakushu to Manabiau Komyuniti no Sozo (Cultivating adult learning: Lifelong learning and the building of a community for learning). Tokyo: Otori Shobo.

Nie, N. H., J. JunN, and K. STEhlik-BARry

1996 Education and Democratic Citizenship in America. Chicago: University of Chicago Press.

Ninomiya, A., ed.

2007 Shimin-sei Keisei-ron (Theories of citizenship development). Tokyo: Foundation of the Promotion of the Open University of Japan.

Nussbaum, M. C.

1997 Cultivating Humanity: A Classical Defense of Reform in Liberal Education. Cambridge, MA: Harvard University Press.

OfFe, C.

1997 "Micro-Aspects of Democratic Theory: What Makes for the Deliberative Competence of Citizens?” In Democracy's Victory and Crisis, ed. A. Hadenius, 81-104. Cambridge: Cambridge University Press.

OKANO, Y.

2009 Shitizunshippu no Seijigaku: Kokumin, Kokkashugi Hihan (Citizenship as politics: A critique of nationality and nationalism). Tokyo: Hakutakusha.

Oshio, T.

2002 Kyoiku no Keizai Bunseki (Economic analysis of education). Tokyo: Nihon Hyōron Sha.

PARKer, W. C.

2001 "Educating Democratic Citizens: A Broad View." Theory into Practice 40: 6-13.

PATRick, J. J.

2003 “Teaching Democracy." ERIC Digest, ED480420.

RANSON, S., and J. STEWART

1989 "Citizenship and Government: The Challenge for Management in the Public Domain.” Political Studies 37: 5-24. 
Roberts, R. N., and A. J. Eksterowics

1996 "Local News, Presidential Campaigns, and Citizenship Education: A Reform Proposal." PS: Political Science \& Politics 29: 66-72.

Romero, L., and E. Del Rey

2004 "Competition between Public and Private Universities: Quality, Prices and Exams." Working Paper 04-64, Economic Series 23 (Universidad Carlos III de Madrid).

Ross, E. W.

2004 "Negotiating the Politics of Citizenship Education." PS: Political Science \& Politics 37: 249-51.

RothsChild, M., and L. J. White

1995 "The Analytics of the Pricing of Higher Education and Other Services in Which the Customers Are Inputs." Journal of Political Economy 103: 573-86.

1993 "The University in the Marketplace: Some Insights and Some Puzzles." In Clotfelter and RothsChild, eds., 1993a, 11-42.

SAKAgAmi, T.

1992 "Knowledge and Order during the French Revolution." Journal of Humanistic Science 70: 23-58.

SATO, R.

2009 “'Shakaijin no Manabi Naoshi Sai-Charenji’ kara Kosatusuru Daigaku no Aratana Yakuwari" (New roles of universities from the viewpoint of "A chance to learn again by members of society"). Journal of Shizuoka University Education 5: 1-8.

Sato, T., H. Takahashi, N. Masuhara, and K. Mori

2005 Shinsetsu Shimin Sanka: Sono Riron to Jissai (New ground in citizen participation: Theory and practices). Tokyo: Kojinsha.

SCHÖN, D. A.

1983 The Reflective Practitioner: How Professionals Think in Action. Hampshire: Ashgate.

Shannon, T. J., and C. A. Schoenfeld

1965 University Extension. New York: Center for Applied Research in Education.

SIEYÈs, E.

1985a “Qu'est-ce que le Tier Etat?” In Ecrits politiques, ed. R. Zapperi, 115-88. Paris: Edition des Archives Contemporaines.

1985b “Préliminaire de la Constitution." In Ecrits politiques, ed. R. Zapperi, 189-206. Paris: Edition des Archives Contemporaines.

SPENCE, M.

1973 “Job Market Signaling." Quarterly Journal of Economics 87: 355-74. 
Suemoto, M.

2004 "Seijin Gakushu ni okeru Jikokettei Genri to Shogai Gakushu no Soshikika" (The principle of self-directedness in adult learning and the development of lifelong-learning system). In Seijin no Gakushu to Shogai Gakushu no Soshikika (Adult learning and development of lifelonglearning systems), ed. The Japan Society for the Study of Adult and Community Education, 280-93. Tokyo: Toyokan.

SugAWARA, S.

2001 "The 'Alien' 's Participation in the Political Process in the Early Period of French Revolution." Journal of the Study of Modern Society and Culture 22: $119-36$.

TANAKA, $M$.

2011 Borantia Katsudo to Otona no Manabi: Jiko to Shakai no Junkanteki Hatten (Volunteer activities and adult learning). Tokyo: Gakubunsha.

2004 "Shakai Kyoiku ni tai suru NPO no Inpakuto" (NPO’s impacts on social education). In NPO no Kyoiku-ryoku: Shogai Gakushu to Shimin-teki Kokyosei (The educational power of the NPO: Civic activism and lifelong learning), ed. K. Sato, 87-107. Tokyo: University of Tokyo Press.

Tsuchiyama, K., and O. Ohyano, eds.

2008 Chiiki Kokyo Seisaku o Ninau Jinzai Ikusei: Sono Genjo to Kadai (Education and training for local public human resource development). Tokyo: Nihon Hyōron Sha.

Tsuji, Y.

2004 "NPO de Hataraku Imi to Sutaffu no Rikiryo Keisei" (Meaning of working for NPOs and competence development of staff members). In NPO no Kyoiku-ryoku: Shogai Gakushu to Shimin-teki Kokyosei (The educational power of the NPO: Civic activism and lifelong learning), ed. K. Sato, 181-98. Tokyo: University of Tokyo Press.

VAn Steenbergen, B., ed.

1994 The Condition of Citizenship. London: Sage.

VEUGELERS, W.

2007 "Creating Critical-Democratic Citizenship Education: Empowering Humanity and Democracy in Dutch Education." Compare: A Journal of Comparative Education 37: 105-19.

Winston, G. C.

1999 "Subsidies, Hierarchy and Peers: The Awkward Economics of Higher Education." Journal of Economic Perspectives 13: 13-36. 